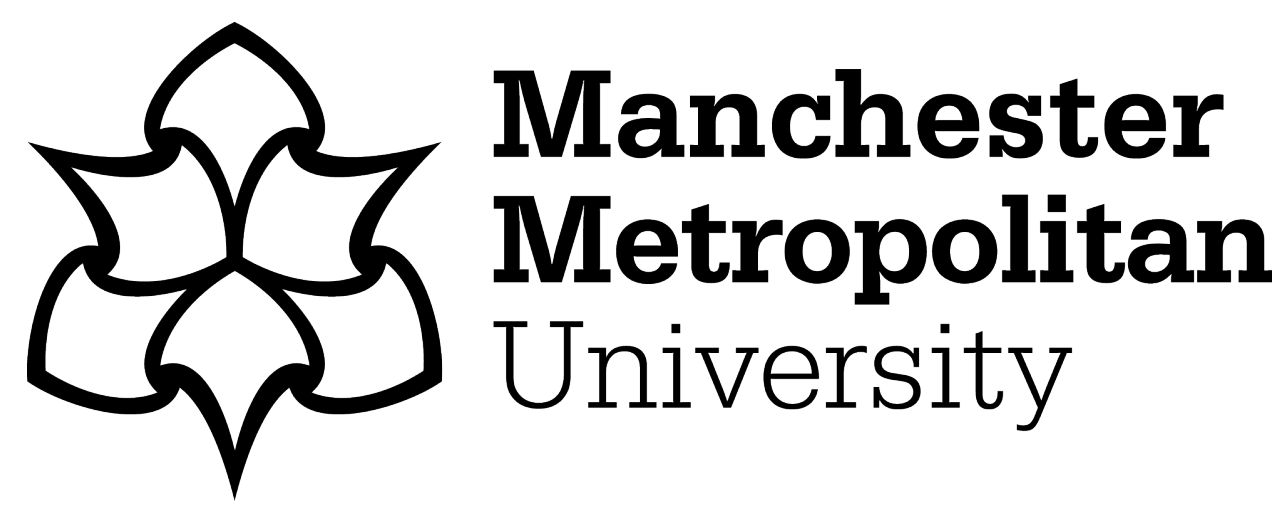

Millward, P, Widdop, P ORCID logoORCID: https://orcid.org/0000-00030334-7053 and Halpin, M (2017) A 'Different Class'? Homophily and Heterophily in the Social Class Networks of Britpop. Cultural Sociology, 11 (3). pp. 318-336. ISSN 1749-9755

Downloaded from: https://e-space.mmu.ac.uk/624973/

Version: Accepted Version

Publisher: Sage

DOI: https://doi.org/10.1177/1749975517712045

Please cite the published version 


\section{A 'Different Class'?: Homophily and Heterophily in the Social Class Networks of Britpop}

\section{Introduction}

Britpop was an 'indie' music scene that broke into the mainstream ascendency in the mid-1990s (Bennett and Stratton 2010; Petridis 2014). Britpop bands, including Blur, Oasis, Pulp, Suede, Elastica and Menswear, shared the common characteristics of referring to British places and culture in their songs and singing in regional British accents (Harris 2010; Miles 1998). This article's title borrows from Pulp's best-selling album 'Different Class' that was released in October 1995, with both the record and individuals related to the group broadly considered to be key to the scene (Hatterley 2011). At the time of Different Class' release The New Melody Express (NME) journalist John Mulvey described the album as 'a memoir of the tense and skint [financially poor] years' set against 'simple revenge on some Year in Province-toting prick' (28 October 1995, p. 52). The theme of performance and representation of social class has stretched across the finite amount of research on the Britpop music scene (Hawkins 2010; Jones 2013; Morra 2014; Wiseman-Trowse 2008). However this article varies from that those studies to explore 'Britpop' through the lens of a formal social network analysis (SNA) in the way that Crossley explored punk and post-punk scenes in the UK (see 2008; 2009; 2015; Crossley et. al 2014). This article moves away from Crossley's work given that discussions about 'social class' are only implicit in his analyses of punk and post-punk. Instead, we break conceptual ground by putting 'social class' at the forefront of a SNA of a music scene-making cultural workforce. Therefore, this article answers two interrelated questions: first, what was/were the social network(s) that made up 'Britpop'? Second, how did social class homophily and/or heterophily exist in the Britpop network? Our literature review begins by discussing scholarship on social class and popular music before unpacking homophily and heterophily.

\section{Literature Review}

Oakley and O'Brien (2016) recently pointed out the continued dominance of the middle and upper classes in the cultural and creative workforces. O'Brien et. al (2016) drew upon the 2014 Labour Force Survey to point out that over 60 per cent of those working in 'music, performing and visual arts' were qualified to at least degree level. Additionally they found musicians to disproportionately hail from 
higher professional and higher managerial original social class positions. Social class is a regular theme in the lyrics of some music genres but tends not to operate in the way it does in theatre, with selective dimensions of working class culture celebrated in popular music (Gildart 2012; Harkness 2014; Hesmondhalgh 2013; McDonald 2009; Palmer 2014; Power et. al 2012; 2016). Indeed, Wiseman-Trowse (2008) found social class to be 'performed' through the actions and managed identities of musicians. 'Authenticity' - which Spracklen $(2011 ; 2013)$ argues to be a vexed concept in cultural sociology - is paralleled with social class representations, with working-class musicians are seen to be more 'real' than those from the middle and upper classes (Wiseman-Trowse 2008). From the North American context, Petersen (1997), Fox (2004) and Harkness (2014) find resonance with this argument in the contexts of country, folk and rap genres. However, Wiseman-Trowse goes further by exploring how performances of class are a way in which the 'meaning' of music is communicated to audiences. Thus, a musicians projected social class may be a performance, drawing upon widely held reference points (lyrics, dress, accent and musicians' biographies), aimed at connecting with a fanbase. In other words, figures in popular culture - such as popular musicians - become part of public understandings about the 'essential properties' of social class. This article does not dispute this narrative but rather tackles another area in which social class and music connect. To be sure, we follow Tilly's (2002: 72) relational realist ontological position 'that transactions, interactions, social ties and conversations constitute the central stuff of social life' and apply it to a social class-focussed SNA of Britpop. Explicitly, we look at whether musicians and other key actors in the scene came together in friendships, sexual relationships and working relationships, exploring processes of social class homophily and heterophily.

'Homophily' works on the premise that birds of a feather flock together (Borgatti et. al 2012). Homophilous networks consist of individuals who are similar in characteristics such as social class, age, etc. (McPherson et. al 2001). Indeed, Huckfeldt (1983) found that even schoolchildren who may not be explicitly aware of 'social class' are more likely to hold friendships with others from similar social locations while the choice of partner might be partially shaped by occupying similar social class positions (Kalmijn and Flap 2001). Homophily limits people's social worlds in a way that has powerful implications for the information they receive, the attitudes they form, and the interactions they experience (McPherson et. al 2001). Homophily can help people access information (Choudhury et. al 2010), bond individuals together to support diffusion of ideas and innovations (Christakis and Fowler 2007) and are crucial in the formation of opinions and norms (Centola et. al 2005). Mark (1998) studied diffusion of music preferences within networks and found that tastes are transmitted through homophilous class networks. Building on Mark's position, Crossley (2015) identified that social 
networks in which music scenes develop/take shape through tend to be homophilic, giving such groups distinct demographic characteristics. In contrast, network heterophily is indicative of a diverse mix of individuals, including those from different social classes. As such, networks are organised through weak ties into a larger heterophilious network. These differences help to foster creativity, which is important for music and other artistic networks. Rodgers' work on diffusion of innovations (2003), Granvettor's theory of weak ties (1973), Simmel's thinking on the stranger (1950), and Lin's theory of social capital (2002) all demonstrate the importance of heterophily in network ties. Heterophily, has been shown to be important in social mobility and employment (Granovettor 1973), social support (Crossley et. al 2015), and diffusion of new conventions and innovations (Rodgers 2003). Thus music scenes, such as Britpop, may develop around diverse groups of individuals from which a distinctive innovative scene or sound develops.

Academic literature on Britpop has argued that some of its associated bands' uses of the Union Jack flag unwittingly excluded a number of social groups from participation and fandom in the scene (Cloonen 1997; Navarro 2016) with Huq (2006: 144) suggesting such imagery implied a sense of compulsory 'whiteness'. Also Benwell (2003) paralleled Britpop with a renewal of hegemonic masculine values communicated in the magazines that were set up to cater for young men in the temporal period (Benwell 2003). Britpop bands were not always male but as Whiteley (2010) suggests, female performers were often sexually-objectified by the 'new lad' media forms. However, it was the 'class war' (Wiseman-Trowse 2008:1) of 'The Battle of Britpop' between Blur and Oasis brought the scene to the cultural mainstream in 1995 (Huq 2006). Spurred on by the media, the two groups engaged in the 'British Heavyweight Championship' (12 August 1995), as the NME dubbed it, in the quest to register the highest charting single. Such was the magnitude of the 'chart battle' it was covered in the national media, including BBC One's flagship ' 9 O'Clock News' programme (Navarro 2016). The opening lines of this feature are of particular pertinence:

It's been described as the 'British Heavy Weight Pop Music Championship'. In one corner, four young middle class men from the South of England, collectively known as Blur, and in the other corner, five young working class men from Manchester called Oasis.

BBC One '9 O'Clock News', 14 August 1995 
Similarly, a day later London Tonight, an ITV evening regional news and magazine, show described the two groups as:

Blur have always played up their cheeky Londoner image, while Oasis revel in being seen as Northern hard men. Blur support Chelsea [Football Club] whereas Oasis are fans of Manchester City [Football Club] and Blur nicknamed Oasis 'Oasis quo' [after the band 'Status Quo'] because they say their songs all sound the same. Oasis say Blur are 'a bunch of middle class art students'.

Friedman et. al (2016) argued that a stage actor is heavily disadvantaged if s/he has the hallmarks of the working classes, such as accents, mannerisms or a given way of addressing others. On the other hand, Wiseman-Trowse (2008) argued that it bestows a sense of 'authenticity' on musicians. During the week that followed the release, Blur sold 274,000 copies of 'Country House' to Oasis' 216,000 copies of 'Roll With It', charting at number one and two respectively. Both subsequently achieved high selling albums - with Oasis' second album selling in excess of four million copies in the UK, becoming the third best-selling album in British history (Bennett and Stratton 2010). It is not clear if representations of working class culture (dis)advantaged the bands but the news items made clear the grounds for social distinctions. Little was made of the fact the all members of the two groups were young men, and there was no mention of the likelihood that all would have probably defined themselves as ethnically 'white'. The markers of difference were starkly drawn from socio-cultural connotations of geography ('from the South of England' or 'cheeky Londoner image' in the case of Blur, and 'from Manchester' and 'Northern hard men' for Oasis) or outright social class position. Oasis described Blur as 'a bunch of middle class art students' as social class ('middle class') and its markers ('art students') were widely known distinctions they formed against their 'rivals'. In return, Blur hurled insults of a similar nature back, referring to Oasis as 'making our vulgarity very tame' (Blur singer Damon Albarn cited Jones 2001). Bourdieu (1990 [2000]: 6) argued that 'taste classifies, and it classifies the classifier. Social subjects, classified by their classifications, distinguish themselves by the distinctions they make'. In front of a watching public, Blur and Oasis mutually classified each other and themselves in their distinctions and this is a key reason why Wiseman-Trowse's (2008) work on the performance and representation of social class is of strong importance to sociologically understanding the movement. 
The socio-political context in which Britpop emerged is significant to these distinctions. Navarro (2015) notes how Britpop emerged as a response to the end of 'Thatcherism'. The political outlook of the period was distinctly neo-liberal, thus favouring economically strong regions of the UK, such as London and the South East of England (Cremin 2012). The relative regional differences in job opportunities increased intra-UK geographical mobility as young people moved to London from elsewhere in the country to gain employment (Porter 1998). As such, Savage et. al (2015: 265-276) demonstrate that spatial inequalities between the 'poor North' and the affluent South-East grew in the 1980s and 1990s. This underlines the significance of media connotations associated with 'Northern' Oasis and 'Southern' Blur. In 1997, Tony Blair brought his 'New' Labour Party into the British government. Both Blur and Oasis publicly supported the politician in his successful General Election campaign despite the regular representations of their apparent class differences. Indeed, representation is just one dimension of the relationship between social class and popular music. For instance, Jones (2013: 60-61) argued that 'northern lasses [and lad]' from the band Kenickie were portrayed in classist terms by the music and mainstream press. However, the siblings that formed one-half of the band, Lauren Laverne and Peter Gofton, hailed from a middle class family in which their father worked as a university lecturer and their mother was a local councillor. This brought into contrast Laverne and Gofton's original social class position and their representation in the music and mainstream media. These tensions encouraged us to break from looking at performances of social location, shifting our gaze toward original social class positions and the relationships and networks of the music scene.

\section{Methodology: A Social Network Analysis of Britpop}

As a methodological framework we follow Crossley's (2008; 2009; 2015) use of SNA of the punk and post-punk scenes in Manchester, Liverpool, Sheffield and London, adopting a mixed method qualitative and quantitative approach. The boundary specification and data collection method was systematic in its approach, and developed in six stages. First, data was derived from several sources: a) a corpus of weekly music magazines from 'indie' facing NME and Melody Maker that focused on the years 19931997; b) a large number of NME's monthly offshoot, Select magazine c) data from biographies and autobiographies of individuals and bands that were involved in the scene and a range of current online archives of print, visual and audio material. This archival dataset offered the most comprehensive way of capturing relational dynamics in a scene which was operating over 20 years ago, replicating some of the ways Crossley (2008; 2009; 2015) explored punk and post-punk networks, but we have to 
acknowledge that the data was produced for commercial purposes and therefore contains biases that might help to sell magazines, books and recorded material.

Second, the boundary of our musicians/actors within the scene was established using the Wikipedia's 'List of Britpop musicians' which named 30 bands/musicians. A strength of this approach was an independent collective consensus of who constituted the scene - thus we did not decide which bands/musicians were initially included/excluded.' The term 'Britpop' clearly has elastic boundaries we did not initially include or induct Kenicke into our network, for example - and thus the inclusion/exclusion of those on the scene is contestable. Third, details were gathered from our media texts to tease out working relationships and 'friendships' from all individuals amongst the 30 bands/musicians. When an additional individual's name came up in three or more texts, s/he was inducted into the network and subsequently searched for in the texts. To ensure edges/connections were robust, there was a cross validation of ties from a minimum of two independent sources. Ultimately, this provided a list of 149 agents who were involved in what we have identified to be the 'inner circle' of Britpop. It is important to note that at this next level not all individuals were musicians rather we follow Crossley $(2008 ; 2009 ; 2015)$ by including those who might also be involved in the business, management or reporting of events and issues (such as Artists and Repertoire - A\&R people, P.R agents, journalists and photographers as well as those who worked in/ran the social spaces in which the key players 'hung out').

The fourth stage, involved, adding attribute data, such as original social class position, defined through the National Statistics Socio-Economic Classification (NS-SEC) schema. However, a further limitation in the study was that even in our large volume this type of data was incomplete for all 149 members of the scene. Fifth, together this data was analysed and understood through a formal SNA. Again, in doing so, we followed the method offered by Crossley (2008; 2009; 2015) in his understandings of punk and post-punk scenes and would rather refer readers to deep discussions of SNA than afford them here (see Scott 2011). However, it is necessary to point out that most variations of quantitative SNA use a variety of mathematical formula to give ways of exploring networks. We defined, populated and visualised our network in NodeXL (see Hansen et. al 2010) and exported this to UCINet (see Borgatti et. al 2012) to generate graph metrics. SNA provides a way of describing and explaining the structure of relationships (Crossley 2015). However, we acknowledge weaknesses in this approach and subsequently our method. We need to be clear, relationships in our method - and often in the approach more broadly - are reduced to 'edges' (lines/links) that connect people, which means it does not take 
into account the 'quality' or endurance of that relationship. In performing this analysis, it was decided that an 'edge' had to be either a friendship or business relationship, not merely reporting to know someone or having shared a tour with an individual. While defining business relationships was a binary decision, coding actors 'knowing' each other through friendships (or not) was more subjective. Thus, in those cases were an individual reported another to be his/her 'friend', 'mate' or 'boyfriend/girlfriend', the link was recorded as an edge. Similarly, if they lived together or told several subjectively defined 'positive' stories about each other we recorded that relationship as an edge. Lots of 'friendships' were recorded in textual material of the time but as Sleeper frontwomen, Louise Wener later recounted, not all of these were genuine ('We were civil but, secretly, there were machinations and schadenfraude. We would look at each other askance, with eyes narrowing and claws were out, mine included' quoted in Mojo Classic 2009: 67). In the light of this, we have to recognise that the data we use might be contaminated by the purpose of the interview with the media form. This has to be acknowledged as a limitation of the data, as it might equally in Crossley's $(2008 ; 2009 ; 2015)$ research which utilised similar methods of data collection, but we were left with no alternative but to accept the individual's report of a friendship existing, as Crossley (2008; 2009; 2015) also did in his research.

Representing a music scene as a social network shows how social actors connect to create structural configurations. SNA graph metrics allow us to examine these configurations at three levels. First, at the whole network level, that is, by looking at the relationships and connectedness of all 149 social actors in Britpop's inner circle. Second at the sub-network level exploring specific groups or clusters of people in the broad network, and third, at the nodal or individual level by looking at the specific attributes and narratives set around individuals in the network. Many cultural sociology/cultural studies examinations of music scenes focus deeply on this third level of analysis by giving biographical accounts of important individuals. Such examples of this type of analysis include Stevenson's (2006) excellent account of David Bowie and Rojek's (2004) impressive historiography on Frank Sinatra which are based on the individual level but are potentially weaker at recognising that, as Crossley (2008; 2009 ; 2015) points out, music production is a collective activity.

Our whole network analysis uses the Clauset-Newman-Moore cluster algorithm to draw out the subnetworks of Britpop, exposing the divisions within the scene (Clauset et. al 2004; Hansen et. al 2010). Prestigious positions in the whole and sub network/s were measured through three centrality measures, 
degree, betweenness and closeness. First, degree centrality is the number of ties an actor has within a network. Second, betweenness centrality is a measure of how often a node (as a social actor/individual) falls along the shortest path connecting two other nodes, such that they might 'broker' between these social actors/individuals (Crossley et. al 2014). Third, closeness centrality is the sum of the path lengths connecting a node (social actor/individual) to every other node in the network, so that higher scores indicate shorter distances. We now move on to focus on the Britpop network.

\section{Britpop's Key Players and Network Structure}

Analyses of the textual dataset led to the inclusion of 149 key players in the Britpop network. The whole Britpop network has a maximum geodesic path of 4 and an average geodesic distance of 2.3. This means that the maximum number of connections to join any two people is network is 4 steps with the mean number of steps at 2.3. The graph density is 0.10 , which means 10 per cent of ties are realised. The whole network's ties and connections were recorded in our dataset and visualised in Figure 1 (below):

INSERT FIGURE 1: Sociogram Showing Clustering of the Britpop Network

Figure 1 identifies 8 subgroups within the Britpop network (labelled G1 to G8) but is clearly dominated by two clusters which are densely connected within, and to a certain degree between, each other (G1 and G2). The remaining clusters are on the edge of the scene. G1 is the largest cluster and is centred on the foci of the London Borough of Camden which has been described as 'the most polarised borough in London [with ...] residents living in one of the most deprived wards in the country, and the gap between the most and least deprived wards is bigger than in any other London borough' (London Borough of Camden 2003: 3). The affluent Primrose Hill lies just one mile away from Camden, where few pockets of social deprivation exist. The central offices of Creation Records were located in Primrose Hill and is important to G2, which is dominated by Oasis and the label (see Hesmondhalgh's 1999 discussion of Creation Records). G3 is made up of members of bands The Bluetones and Dodgy, a friendship group that lived together and near each other in Hounslow, G4 is made up of members of Gene who 'always hated being bundled in with the Britpop bands' (see Wilde 2012) and their 
associates (including music producer Stephen Street). Meanwhile G5 consists of several individuals residing in Camden, who were never strongly connected to members of G1 (or G2), while G6 is made up of the Northern Irish band Ash, who also did not identify with the label 'Britpop'. G7 centred on Hut Records manager Dave Boyd and includes frontman from The Auteurs Luke Haines, while G8 was set around the only loosely connected singer Rick Whitter, from York-based band Shed Seven. To begin to address issues surrounding connections in the network, we used the centrality measures of degree, betweenness and closeness offered in Table 1 (below), which aggregates the top-10 ranked individuals from the network according to these measures, to piece together influential members of the scene. All of these individuals belonged to either $\mathrm{G} 1$ or $\mathrm{G} 2$.

INSERT Table 1: Centrality Measures

Of the ten with the highest centrality measures, only four- Oasis' Liam Gallagher and Noel Gallagher, Powder's Pearl Lowe and Limousine's Simon Mason - are musicians. From these, Simon Mason's (2013) autobiography extensively details him selling drugs to unnamed Britpop artists. The remaining seven work in public relations ([hereafter P.R.], Savidge and Best), journalism (Harris - although he also set up a small independent record label, Fierce Panda) or were DJs (Tunkin, Jackson and Lewis although the latter played bass guitar for Paul Weller). Betweenness is also dominated by nonmusicians, such as those who work in P.R. (Best, Savidge, Hall and Hopkins), journalists (Harris and Williams - who worked together at the NME and co-founded Fierce Panda), DJs (Lewis) and photographer Brian Cannon - thus the nexus of press and commercial agents dominate the shortest paths across the network. Once more, P.R. agents (Best, Savidge and Hopkins), journalists (Harris and Williams), and DJs (Lewis and Jackson) are dominant in the ranked closeness 'top 10' list. Above all else, Table 1 is dominated by the presence of John Harris, who is highest ranked in all three measures, P.R. agency owners, Phill Savidge and John Best, nightclub DJs, lan Jackson and Andy Lewis and Oasis' Noel Gallagher and Liam Gallagher (all later discussed). At this point, as the two largest clusters, and therefore offering the 'critical mass of the scene' (see Crossley 2015), we shift our focus to G1 and G2.

\section{G1: The Camden Cluster}


Figure 1 shows members of Blur, Elastica, Suede, Pulp and Menswear are located in G1. Additionally, a large number of non-musicians populate this group. These non-musicians include P.R. agents Phill Savidge and John Best, who set up 'Savage and Best PR', a company that was based in Camden and carried out PR work for bands including Blur, Elastica, Suede, Pulp and Menswear. It also included Food Records' co-owner Andy Ross, who worked in the same building off Arlington Road (in Camden) as Savage and Best PR. Figure 1 and Table 1 show that DJs Paul Tunkin, lan Jackson and Andy Lewis, who ran 'Blow Up!' - a cult club night above The Laurel Tree public house in Camden - were also well connected in G1. This club was an important 'foci' for the network. Figure 2 (below) and Table 2 (below) isolate those highlighted as G1 members in Figure 1, discounting links to beyond its boundaries.

\section{INSERT Figure 2}

INSERT Table 2

There were 61 actors in G1. The graph metrics showed an average geodesic distance of 1.91 with a maximum geodesic distance of 5 . G1's density is 0.27 . Compared to the whole network, G1 has a shorter average geodesic distance and higher density. While musicians made up a majority of the group, it is noticeable that the data in Table 2 shows that musicians did not make up the majority of the best connected in people in the cluster. From these, Betweenness showed Pearl Lowe to be the best 'broker' between actors in the group. Lowe's (2008) autobiography attests that between 1994 and 1997 she fronted the band Powder - an act signed by Parkway Records (a label put together by PR agents Phill Savidge and John Best) - and lived in Camden and then Primrose Hill. Although she is recorded as a musician, her band released only three singles in the period, the highest charting at number 72 . Due to her connections in the scene, she met and formed a long-term relationship with Supergrass drummer Danny Goffey, son of a BBC 'Top Gear' programme presenter father and a former Labour Party councillor mother. Lowe also hailed from an artistic background with her mother a high-end interior designer (Lower managerial and professional occupations from NS-SEC) who was part of north London's 'creative class' (Florida 2002). Similarly, Salad frontwoman Marijne van der Vlugt hailed from the 'creative class', as her father is the Dutch television actor/voice over artist Bram van der Vlugt. Marijne Van der Vlugt was connected but her band also experienced only modest commercial success, despite recording two albums their highest placing was number 16. PR agents Best and Savidge were near the top of all centrality measures in G1. Given that they had a different occupation to the musicians, it is important to note that they employed other PR agents (such as Polly Birkbeck, now owner of Complete Control PR agency) qualifying them as the highest NS-SEC level. Indeed, Savidge 
and Best's job was to ensure the bands and artists they represented received media coverage and so they brokered relationships with those in other skilled professional occupations, including record label personnel (such as Saul Galpern), journalists and band managers (such as Adrian Webb). Blow Up! DJs Paul Tunkin and Andy Lewis both attended Art College before, with lan Jackson, they set up their club night club. Little is known about their social class backgrounds but it appears that none had professional occupations before moving to London. Indeed, Tunkin moved to Camden from Southend, where he had known Todd Permenter, who was the original drummer in the band Menswear, but beyond that, little is known about his background.ii From the other musicians situated amongst the best connected in G1, Blur guitarist Graham Coxon (who met Blur bassist Alex James while studying Fine Arts at Goldsmiths College) hailed from a background where his father was a clarinet player and army bandleader while his mother worked as a language educator. Simon Mason, another central actor, came from 'a reasonably well-to-do family in Weston-super-Mare' (Mason 2013: 3) and a private boarding school. Lush singer Miki Berenyi, whose band Lush predated 'Britpop', was in a relationship with PR agent John Best in the mid-1990s and hailed from a family where her mother was a wellestablished Japanese actress and her father was a Hungarian journalist of strong repute.

Well-known players in G1, who are defined as such according to their band's status and/or their media presence, include Elastica singer Justine Frischmann, Suede's Brett Anderson, Blur's Damon Albarn and Pulp's Jarvis Cocker. Due to their public profiles it is worth exploring their original social class backgrounds alongside those who were best connected. Indeed Justine Frischmann's father was a multi-millionaire and the chairman of an internationally recognised firm of consulting engineers (Higher managerial and professional occupations from NS-SEC). Frischmann's boyfriend at the beginning of the period, Brett Anderson hailed from a working class background in Haywards Heath, a distinctly middle class West Sussex town. Frischmann's boyfriend by 1995, Damon Albarn, came from a middle class background with his father a television arts programmer (Higher managerial and professional occupations from NS-SEC) who also managed the 1970s psychedelic 'prog-rock' band Soft Machine. Jarvis Cocker's father was a DJ and actor but left the family to move to Australia when Cocker was seven. Jarvis Cocker was subsequently raised in a single parent family in which his mother worked for a 'fruit machine' gambling company. Her job was to collect money from one-arm bandits and report any faults on the machines. These four individuals did not come from the same social class backgrounds.

Three key trends emerge from $\mathrm{G} 1$ analysis. First, there are a sizable number (six from ten in each of Betweenness, closeness and degree measures of centrality) that are not musicians but have jobs that 
are related - both clearly and less clearly (in the case of the DJs) - to the 'music business'. Thus, their occupations rather than those of an original social class position, should be taken into account in the analysis of the group. Second, although there is a heavy representation of musicians hailing from higher social classes and 'creative classes' (Florida 2002), the group appears to be marked by class heterophily. Indeed, the common theme appeared not to be original social class background but their keenness to socialise in the public houses and nightclubs of Camden, especially including Blow Up! which seems to have brought the group together. Third, despite all musicians in key Britpop bands such as Suede, Blur, Pulp and Elastica being part of G1, members of those bands - with the exceptions of Coxon and Welch - tend not to be the best connected in the group.

\section{G2: Oasis and Creation Records}

Figure 1 shows that members of Oasis form a significant part of $\mathrm{G} 2$. As in $\mathrm{G} 1$, there are a large number of non-musicians in this group, including Creation Records owner Alan McGee and NME journalists Simon Williams and John Harris (who together co-owned the Camden-based indie record label Fierce Panda). The group is less defined by one geographical position than $\mathrm{G} 1$. At the beginning of 1994, all five members of Oasis lived in their home town of Manchester but by the end of the year singersongwriter and guitarist Noel Gallagher had relocated to Camden (see Harris 2003; 2010). Nevertheless, they were still known as a 'Manchester band', bringing with them the label associated with stereotypes of the northern city (see Wiseman-Trowse 2008: 146-167 for discussions on Manchester, social class and indie music). Similarly, the Glaswegian Alan McGee had also moved to the capital some years before - although he first saw Oasis play the King Tut club in home city after he relocated - with his company's office situated in Primrose Hill. The relocation Noel Gallagher and Alan McGee undertook was shared with other musicians such as Liam Gallagher and Tim Burgess from this cluster and mirrored those trends of moving to London to increase employment prospects in the wider society.

G2 included musicians that remained from the 'Baggy' British independent scene which flourished five years before the 'start' of Britpop, particularly those that hailed from Manchester, such as Shaun Ryder and Bez from The Happy Mondays, Tim Booth from James, and The Charlatans' Tim Burgess and Mark Collins, whose band were experiencing a renaissance in the new scene. Many of these 'Baggy' veterans knew Noel Gallagher from his position as a roadie and technician for the Manchester band, The Inspiral Carpets, a position he held between 1988 and 1990. As with G1, Figure 3 (below) and 
Table 3 (below) isolate those highlighted as $\mathrm{G} 2$ members in Figure 1, discounting links to beyond its boundaries.

\section{INSERT Figure 3 \\ INSERT Table 3}

There were 58 actors in G2. Its maximum geodesic distance is 4 , with an average of 1.88 . While the average geodesic distances in $\mathrm{G} 1$ and $\mathrm{G} 2$ are similar it is noticeable that there is a smaller maximum distance in G2. However a smaller percentage of ties are realised in this network with a slightly lower graph density of 0.22 . Data in Table 3 shows that only eleven actors make up the 30 slots allocated in the top-10 ranks for each of the three measures of centrality. Those individuals are Noel Gallagher, Liam Gallagher, Paul Arthurs, Tony McCarroll, Paul McGuigan, Tim Burgess, Alan McGee, Jeff Barrett, Johnny Hopkins, Terri Hall and John Harris. The first five of these were original members of Oasis with one further musician, Tim Burgess, amongst the number. There are two direct members of Oasis' record label, Alan McGee and in-house PR agent Johnny Hopkins an additional PR agent, Terri Hall, who later worked with Oasis after the closure of Creation Records and had previously worked with many 'Baggy' bands. In addition, Jeff Barrett worked for Alan McGee as a general assistant at Creation Records between 1985 and 1988, before he launched Heavenly Records. The best-connected actors in $\mathrm{G} 1$ are Oasis and members of the support team from Creation Records.

Qualitative material in Tony McCarroll's (2011) autobiography shows that he, Liam Gallagher, Paul Arthurs and Paul McGuigan were a tightly knit group of friends from the working class districts in south east Manchester (the Gallaghers from Burnage, Arthurs from Longsight, and he and McGuigan from Levenshulme). All were born to Irish migrant families. Noel, the older Gallagher brother, joined the band in 1991. The Gallaghers hailed from a family headed by a single mother who worked in a factory (routine occupations based on NS-SEC) while McCarroll and Arthurs' fathers were builders and plasterers making them from semi-routine occupations (NS-SEC). They shared the broad position of 'working class'. Burgess was from a similar class location as members of Oasis, although he did not encounter them until the 1990s - his autobiography testifying that his mother worked in a newsagent's shop in Northwich, a small town less than 20 miles away from where Oasis grew up.

Meanwhile, Alan McGee also hailed from a working class background, his mother 'doing the books for the car mechanics where [his] dad worked as a panel-beater' (McGee 2013: 1). In other words, McGee hailed from a 'skilled manual' family (lower supervisory and technical occupations - NS-SEC). To our 
knowledge, there is no publicly available information on the original class background of Johnny Hopkins or Jeff Barrett but both performed public relations duties at Creation Records, before the later founded Heavenly Records. Prior to working at Creation Records, Barrett worked as singles buyer for a record shop in Plymouth while Hopkins had studied at the University of Hull. Much like fellow PR agent Terri Hall and journalist John Harris, Hopkins and Barrett held employed professional positions in the network, all in occupational Higher managerial and professional occupations based on NS-SEC. John Harris grew up in the affluent Manchester suburb of Wilmslow, graduated with a degree in Politics, Philosophy and Economics from Oxford University and is the son of a university lecturer and a teacher.

Three key trends emerge from our analysis of $\mathrm{G} 2$. First, in common with $\mathrm{G} 1$ there are a sizable number (five out of eleven names) of those with high measures of centrality that are part of the 'music business' but not musicians. Second, the six musicians that featured amongst the best connected all hailed from the 'working classes', with all coming from Manchester or its nearby towns. In other words, there exists a social class homophily amongst musicians - in contrast to G1. Third, this group of musicians are based upon the members of Oasis, the most commercially successful band in $\mathrm{G} 2$ (and perhaps the whole Britpop scene) with the other musician who was best connected in G2, Tim Burgess, the lead singer of The Charlatans, a band who achieved three 'number one' albums in the 1990s. Thus, unlike $\mathrm{G} 1$, the 'highest profile' musicians were amongst the best connected in $\mathrm{G} 2$.

\section{Conclusions}

Literature on the cultural workforce of music production contains some findings that initially look contradictory. For instance, O'Brien et. al (2016) found that musicians are likely to be originally drawn from higher professional and higher managerial social class positions, while other research suggests that the music industry encourages popular musicians to present themselves as from the working classes (Fox 2004; Harkness 2014; Hawkins 2010; Jones 2013; Morra 2014; Petersen 1997), with such positions generally celebrated in popular music (Gildart 2012; Harkness 2014; Hesmonhalgh 2013; McDonald 2008; Palmer 2014; Power et. al 2012; 2015). Indeed, Wiseman-Trowse even goes as far as to suggest that social class becomes a way of conveying 'meaning' through music. This article does not contest any of these positions but rather emerges from a relational realist ontological position (Tilly 2002) to question whether musicians and other key actors in the Britpop movement clustered together under their original social class positions, thus exploring homophily and heterophily in a music scene. This means we have broken from previous studies of Britpop which have stressed representations of 
class rather its impact of forming friendships and relationships. In this respect it echoes research into the influence of social class on choices of school friendships (Huckfeldt 1983) and, into adulthood, mating partners (Kalmijn and Flap 2001).

Academic work that has discussed social class in Britpop has looked at the movement as either middle or working class (see Hatherley 2011; Hawkins 2010; Huq 2006; Jones 2013) assuming the movement to be singular when, in fact, it was not. Accordingly, we have argued that the whole Britpop social network was social class heterophilic, with its members arriving from different social locations. However, on further analysis through a Clauset-Newman-Moore cluster algorithm, Britpop's cultural workforce - encompassing A\&R people, PR agents, journalists, band managers, record producers and record label owners as well as musicians - is broken into eight groups, of which the majority of members fall into one of two distinct main clusters, G1 and G2. Cross sub-network connections existed between some members of groups, but despite some in G1 and G2 living, working and spending leisure time in the same physical space, divides broadly fell between those hailing from the 'North' and those from 'South'. According with Wiseman-Trowse's findings (2008) it is not surprising that the media, including BBC's '9 O'Clock' news, were quick to draw on the social class differences between bands such Oasis and Blur, their claims partially based upon cultural stereotypes of the 'North' and 'South'.

The exploration of $\mathrm{G} 1$, who were mainly based in the socially diverse Camden borough of London, suggested that group members hailed from a range of social class background. In other words, G1 was a heterophilic network in class terms. Hatherley (2011) held that Britpop bands that grew associations with Camden, such as, Pulp and Blur - were more 'creative' than Britpop bands from outside the cluster (Nolan and Roach, 2015). 'Creativity' is notoriously difficult to measure (O'Brien 2013) but if these assumptions hold firm, they would be typical of a socially heterophilic network and would reflect the socially mixed immediate urban environment that makes up Camden's populace. G1 contained a large number of connections that were romantic relationships and this is less typical of a social class heterophilic network. Quite clearly the social spaces such as the Blow Up! in Camden served as a hub in which relationships and interactions between those from the scene, blossomed and were of key importance in overcoming typical divisions in heterophilic networks, while maintaining some of the innovations that are typically offered in such social formations. 
Musicians in G2 were homogenously 'working class'. By the mid-point of the scene, members of this group lived in different cities and in more disparate locations to each other than $\mathrm{G} 1$, but most originally hailed from Manchester and its surrounding hinterlands. It was a more homophilic social class network than G1. Members of Oasis were amongst the best connected in this group. Once again, it is necessary to point out that 'creativity' is difficult to measure in music but bands in this group were often criticised for a lack of innovation by some segments of the music press (Bennett and Stratton 2010; Harris 2003; 2010). If this criticism did hold up, it would be typical of homophilic networks which are typically less innovative than heterophilic communities. It is also unsurprising that many of the nonfamilial relationships in this group long pre-dated Britpop, but it is more surprising that so few romantic interactions took place in $\mathrm{G} 2$ - a factor which is probably accounted for in terms of gender and sexuality sameness rather than social class homophily.

John Harris was clearly a broker between the two groups and when the two groups were detached he held less power in the network. His social power came from fusing $\mathrm{G} 1$ and $\mathrm{G} 2$ together and his cultural power came from his brokerage of discrete networks - with his connections to the cultural workforce involved in making the scene, including other journalists, record label owners, band managers, DJs, musicians and, crucially, PR agents. Harris and PR agents, such as Savidge and Best, mediatised the scene, and did so using mechanisms that played on the above stated cultural stereotypes. Whilst the music these bands produced was not contrived by them, the production of the scene was broadly developed through the professional music journalism industry ready for consumption by the public.

This article's findings are sociologically important for three reasons. First, we hope this article underlines the need for more interrogation of how original class position shapes connections and relationships between individuals. In this case, the individuals are those young people engaged in the production of a music scene, through their various professional roles, exploring the extent to which social class homophily and heterophily existed. This is important for researchers in the fields of both cultural production/consumption and, more broadly, the cultural sociology of social class. Second, our article contributes to the approach of using social network analysis as a tool to relationally understand the production of a music scene, borrowing influence from Crossley (2008; 2009; 2015), but building an explicit focus on social class into this analysis. Further research of this type might take place in the 
context of other music scenes from both the U.K. and across the world. In such cases, if the possibilities present themselves for a full data set on original social class position, autocorrelation tests could take place to investigate whether friendship is patterned by class across a whole network or subnetwork, not just - as we have here - focussing on those individuals who were 'best connected' (as defined through high centrality measures). This is worthy of future research. Third, we hope the article makes a full contribution to the literature on music and social location by stepping away from class performance and representations and into a relational realist position. We acknowledge that this involves discussing the issues away from a social constructivist position but we see our results adding to the literature in this area rather than disputing the findings offered by those such as WisemanTrowse (2008) on this important cultural sociological theme.

\section{References}

BBC One (1995) '9 O'Clock News', 14 August.

Bennett, A. (2010) 'Missing Links: Britpop Traces, 1970-1980' In: A. Bennett and J. Stratton (Eds.) (2010) Britpop and the English Music Tradition, Farnham: Ashgate.

Bennett, A. and Stratton, J. (2010) 'Introduction' In: A. Bennett and J. Stratton (Eds.) (2010) Britpop and the English Music Tradition, Farnham: Ashgate.

Benwell, B. (2003) 'Ambiguous masculinities: heroism and anti-heroism in the men's lifestyle magazine' The Sociological Review, 51(1): 151-168.

Berliner, P. J. (1994) Thinking in Jazz: The Infinite Art of Improvisation. Chicago: University of Chicago Press.

Borgatti, S.P., Everett, M.G. and Johnson, J.C. (2013) Analyzing Social Networks. London: Sage.

Bourdieu (1990 [2000]) Distinction: A Social Critique of the Judgement of Taste. Boston/London: Harvard University Press.

Centola, D., Willer, R. and Macy, M. (2005) 'The Emperor's Dilemma: A Computational Model of Self-Enforcing Norms' American Journal of Sociology, 110(4): 1009-40.

Christakis, N.A., Fowler, J.H. (2007) 'The Spread of Obesity in a Large Social Network over 32 Years' New England Journal of Medicine, 357:370-379. 
Choudhury, M., Sundaram, H., John, A., Seligmann, D.D., and Kelliher, A. (2010) "Birds of a Feather": Does User Homophily Impact Information Diffusion in Social Media? arXiv preprint arXiv:1006.1702.

Cloonan, M. (1997) 'State of the nation:"Englishness," pop, and politics in the mid-1990s' Popular Music \& Society, 21(2): 47-70.

Cremin, C. (2012) 'The social logic of late capitalism: Guilt fetishism and the culture of crisis industry' Cultural Sociology, 6(1): 45-60.

Crossley, N. (2008) 'Pretty Connected: The Social Network of the Early UK Punk Movement' Theory, Culture \& Society, 25(6): 89-116.

Crossley, N. (2009) 'The man whose web expanded: Network dynamics in Manchester's post/punk music scene 1976-1980' Poetics, 37(1): 24-49.

Crossley, N. (2015) Networks of sound, style and subversion: The punk and post-punk worlds of Manchester, London, Liverpool and Sheffield, 1975-80. Manchester: Manchester University Press.

Crossley, N., Bellotti, E., Edwards, G., Everett, M.G., Koskinen, J., and Tranmer, M. (2015) Social Network Analysis for Ego-Nets. Sage London.

Crossley, N., McAndrew, S. and Widdop, P. (2014) Social Networks and Music Worlds (Eds.). Abingdon: Routledge.

Florida, R. (2012) The Rise of the Creative Class and How It's Transforming Work, Life, Community and Everyday Life. London: Basic Books.

Fox, A.A. (2004) Real Country: Music and Language in Working-Class Culture. London: Duke University Press.

Friedman, S., O'Brien, D. and Laurison, D. (2016) Like Skydiving without a Parachute': How Class Origin Shapes Occupational Trajectories in British Acting. Sociology, (online first).

Gildart, K. (2012) 'From 'Dead End Streets' to 'Shangri Las': Negotiating Social Class and Post-War Politics with Ray Davies and the Kinks' Contemporary British History, 26(3): 273-298.

Granovetter, M. S. (1973). "The Strength of Weak Ties". American Journal of Sociology, 78 (6): 1360-1380.

Hansen, D., Shneiderman, B. and Smith, M.A. (2010) Analyzing social media networks with NodeXL: Insights from a connected world. New York: Morgan Kaufmann.

Harkness, G. (2014) Chicago Hustle and Flow. Minnesota: University of Minnesota Press.

Harris, J. (2003) Britpop! Cool Britannia and the Spectacular Demise of English Rock. London: HarperCollins. 
Harris, J. (2010) The Last Party: Britpop, Blair and the Demise of English Rock. London: HarperCollins.

Hatherley, O. (2011) Uncommon: An Essay on Pulp. Winchester: Zero Books.

Hawkins, S. (2010) 'Unsettling Differences: Music and Laddism in Britpop' In: A. Bennett and J. Stratton (Eds.) (2010) Britpop and the English Music Tradition, Farnham: Ashgate.

Hesmondhalgh, D. (1999) 'Indie: The institutional politics and aesthetics of a popular music genre' Cultural Studies 13(1): 34-61.

Hesmondhalgh, D. (2013) Why Music Matters. John Wiley \& Sons: Chichester.

Huckfeldt, R.R. (1983) 'Social contexts, social networks, and urban neighborhoods: Environmental constraints on friendship choice' American Journal of Sociology, 89(3): 651-669.

Huq, R. (2006) Beyond subculture: Pop, youth and identity in a postcolonial world. Abingdon: Routledge.

ITV (1995) 'London Tonight' 15 August.

Jones, L. (2001) 'All a bit of a blur' The Telegraph, 5 June http://www.telegraph.co.uk/culture/4723916/All-a-bitof-a-blur.html [accessed 7/2016].

Jones, R.E. (2013) Clampdown: Pop-Cultural Wars on Class and Gender. Winchester: Zero Books.

Jonze, T. (2014) 'Blur's war against grunge: could the Brits take on U.S. pop again?' The Guardian, 7 March https://www.theguardian.com/music/musicblog/2014/mar/07/blurs-girls-boys-britpop-american-grunge [accessed 7/2016].

Kalmijn, M. and Flap, H.D. (2001) 'Assortative meeting and mating: Unintended consequences of organized settings for partner choices' Social forces, 79(4): 1289-1312.

Lin, N. (2002) Social Capital: A Theory of Social Structure and Action. Cambridge: Cambridge University Press. London Borough of Camden (2003) 'Social Inclusion Strategy' www.camden.gov.uk [accessed 8/2016] Lowe, P. (2008) All That Glitters. London: Hodder Publishers.

Mason, S. (2013) Too High, Too Far, Too Soon: Tales from a Dubious Past. London: Mainstream Publishing. Mark, N. (1998) Birds of a feather sing together. Social Forces, 77(2): 453-485

Martin, P. J. (2006) Music and the sociological gaze: Art worlds and cultural production. Manchester University Press

McCarroll, T. (2011) Oasis the Truth: My Life as Oasis's Drummer. John Blake Publishing Ltd 
McDonald, C.J. (2009) Rush, Rock Music, and the Middle Class: Dreaming in Middletown. Bloomington: Indiana University Press.

McGee, A. (2013) Creation Stories: Riots, Raves and Running a Label. London: Pan.

McPherson, M., Smith-Lovin, L., Cook, J. M. (2001) Birds of a feather: Homophily in social networks. Annual Review of Sociology, 27: 415-444.

Miles, S. (1998) Consumerism: As a Way of Life. London: Sage.

Mojo Classic (2009), p. 67

Morra, I. (2013) Britishness, Popular Music, and National Identity: The Making of Modern Britain. London: Routledge.

Mulvey, J. (1995) 'Pulp: Different Class' The New Musical Express, 28 October, p.52

Navarro, B. (2016) 'Creative industries and Britpop: the marketisation of culture, politics and national identity' Consumption Markets \& Culture, 19(2): 228-243.

O'Brien, D., Laurison, D., Friedman, S., Miles, A. (in press 2016) 'Are the Creative Industries Meritocratic?' Cultural Trends 25:3, 182-193.

Oakley, K. and O'Brien, D. (2016) 'Learning to labour unequally: Understanding the relationship between cultural production, cultural consumption and inequality" . Social Identities, 22(5): 471-486.

Palmer, A. (2014) "'In a Land that I Love": Working-Class Identity and the End of Empire in Ray Davies' Arthur or the Decline and Fall of the British Empire' Popular Music and Society, 37(2): 210-232.

Peterson, R.A. (1997) Creating Country Music: Fabricating Authenticity. Chicago: University of Chicago Press. Petridis, A. (2014) Britpop and Kurt Cobain 20 Years On - Don't Look Back in Anger' The Guardian, 3 April https://www.theguardian.com/music/2014/apr/03/britpop-kurt-cobain-20-years-nirvana [accessed 7/2016].

Porter, R. (1998) London: a social history. Boston: Harvard University Press.

Power, M.J., Dillane, A. and Devereux, E. (2012) 'A push and a shove and the land is ours: Morrissey's counterhegemonic stance (s) on social class' Critical Discourse Studies, 9(4): 375-392.

Power, M.J., Dillane, A. and Devereux, E. (2016) "II sing out to the youth of the slums": Morrissey and Class Disgust' Popular Music and Society, 39(5): 547-562.

Rogers, E.M. (2003). Diffusion of innovations (5th ed.). New York: Free Press.

Rojek. C. (2004) Frank Sinatra. Polity Press. 
Savage, M., Devine, F., Cunningham, N., Taylor, M., Li, Y., Hjellbrekke, J., Le Roux, B., Friedman, S. and Miles, A. (2013) 'A new model of social class? Findings from the BBC's Great British Class Survey experiment' Sociology,47(2): 219-250.

Savage, M., Cunningham, N., Devine, F., Friedman, S., Laurison, D., McKenzie, L., Miles, A., Snee, H. and Wakeling, P. (2015) Social class in the 21st century. Milton Keynes: Pelican.

Scott, J. (2011) Social Network Analysis. London: Sage.

Simmel, G., Wolff, K. (Trans.) (1950) The Sociology of Georg Simmel. New York: Free Press.

Spracklen, K. (2011) 'Dreaming of drams: Authenticity in Scottish whisky tourism as an expression of unresolved Habermasian rationalities' Leisure Studies, 30(1): 99-116.

Spracklen, K. (2013) 'Nazi punks folk off: leisure, nationalism, cultural identity and the consumption of metal and folk music' Leisure Studies, 32(4): 415-428.

Stevenson, N. (2006) David Bowie: Fame, Sound and Vision. Cambridge: Polity Press.

Tilly, C., 2002. Stories, Identities, and Political Change. Oxford: Rowman \& Littlefield Publishers.

Whiteley, S. (2010) 'Trainspotting: The gendered history of Britpop' In: A. Bennett and J. Stratton (Eds.) (2010) Britpop and the English Music Tradition, Farnham: Ashgate.

Wilde, J. (2012) 'Gene's Martin Rossiter Interviewed: "Pulp And Blur Can Fck Off To Butlins"' Sabotage Times, 24 November http://sabotagetimes.com/music/genes-martin-rossiter-interviewed-pulp-and-blur-can-fck-off-tobutlins [accessed 8/2016] Wiseman-Trowse, N. (2008) Performing Class in British Popular Music. Basingstoke: Palgrave MacMillan 
Figure 1: Clustered Sociogram of Britpop Network (G1-G8), N=149

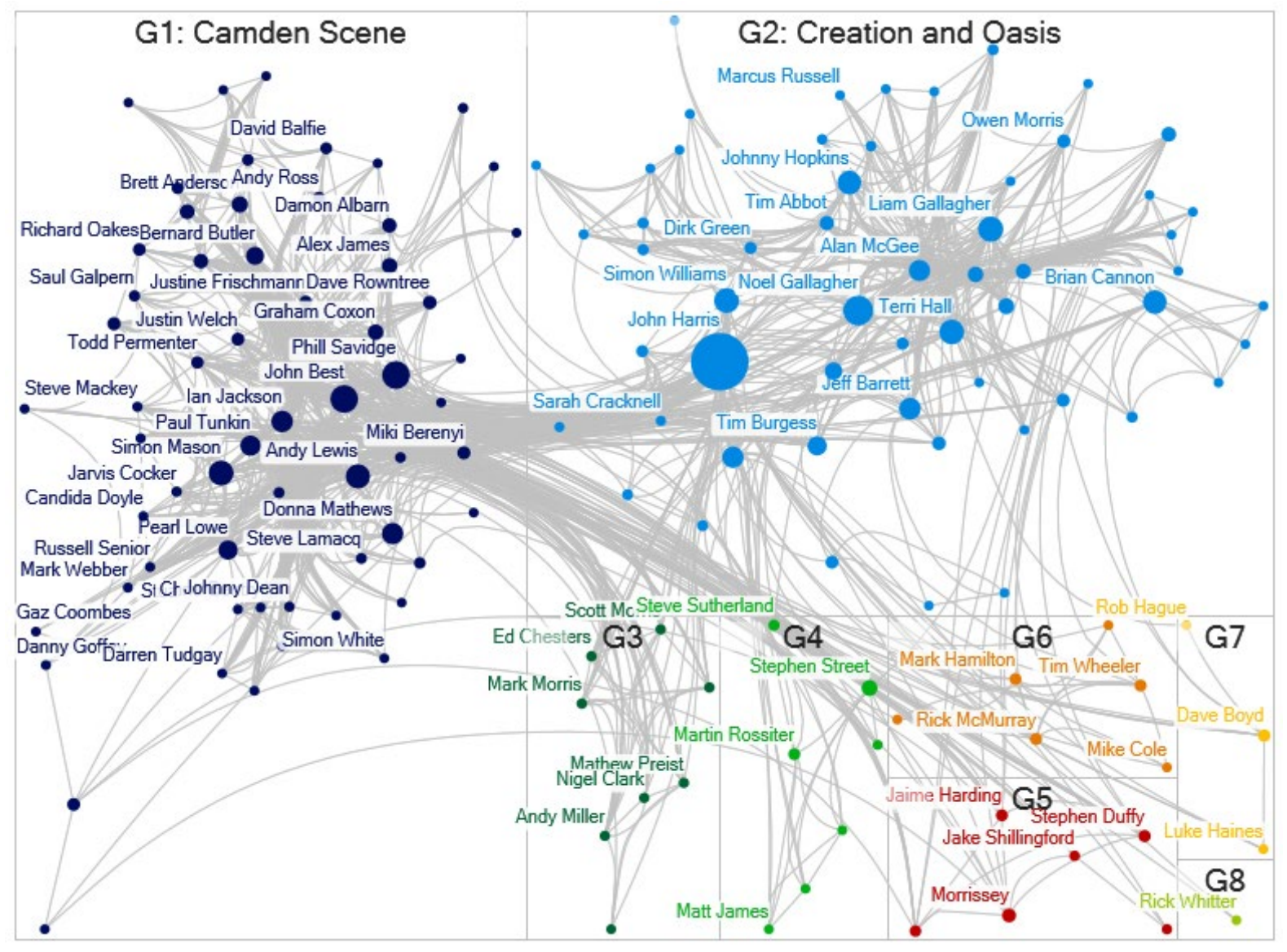


Table 1: Centrality Measure Ranking of Britpop Network (G1-G8)

\begin{tabular}{cccc}
\hline Rank & Betweenness & Closeness & Degree \\
\hline 1 & John Harris & John Harris & John Harris \\
2 & Noel Gallagher & John Best & Andy Lewis \\
3 & John Best & Phil Savidge & lan Jackson \\
4 & Phil Savidge & Noel Gallagher & Paul Tunkin \\
5 & Liam Gallagher & Andy Lewis & Phil Savidge \\
6 & Simon Williams & Liam Gallagher & John Best \\
7 & Terri Hall & lan Jackson & Noel Gallagher \\
8 & Andy Lewis & Simon Williams & Liam Gallagher \\
9 & Johnny Hopkins & Alan McGee & Simon Mason \\
10 & Brian Cannon & Johnny Hopkins & Pearl Lowe \\
\hline
\end{tabular}


Figure 2: G1 sub-network, scaled by Betweenness

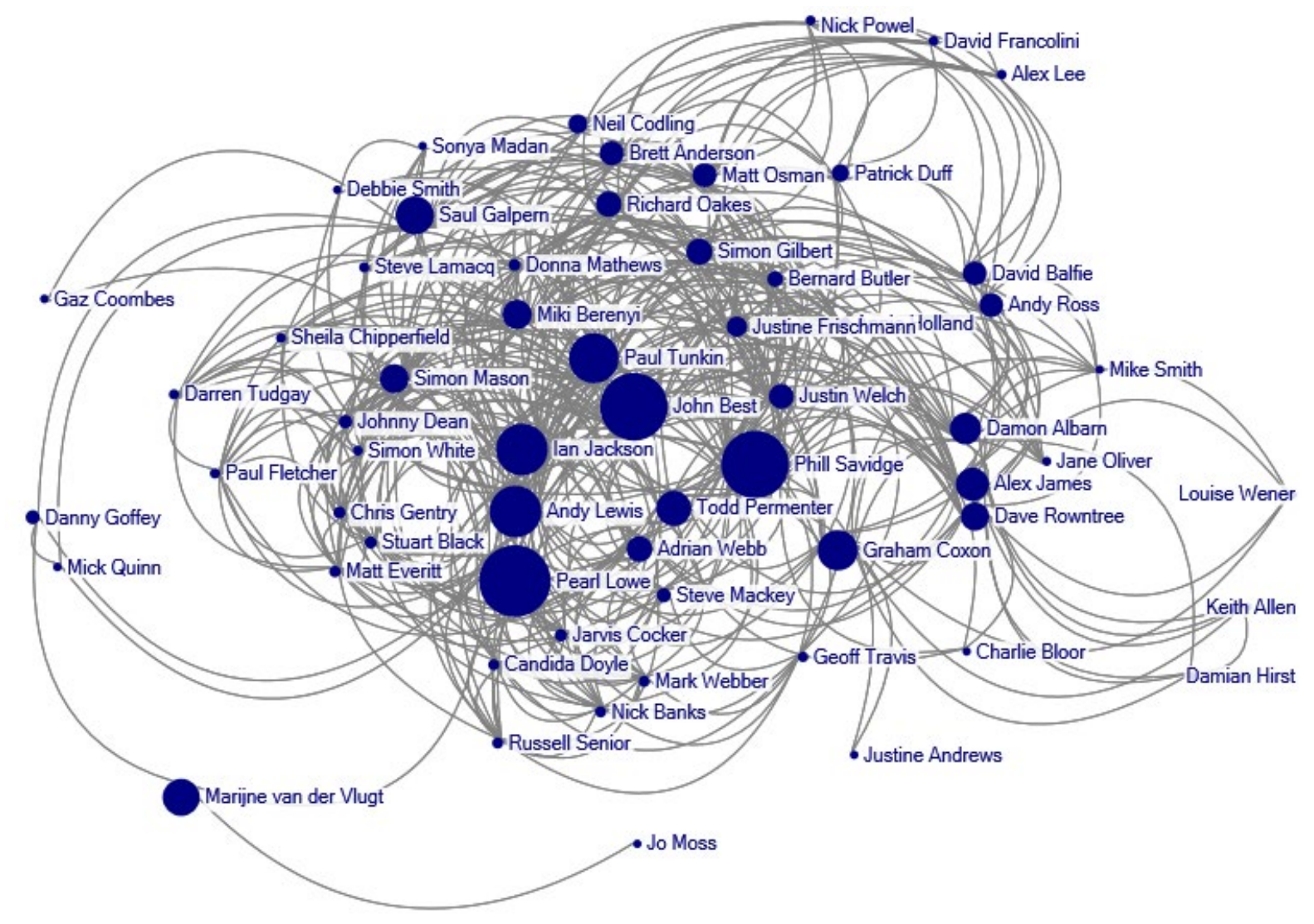


Table 2: Centrality Measure Ranking of Bounded G1 Network

\begin{tabular}{clll}
\hline Rank & Betweenness & Closeness & Degree \\
\hline 1 & Pearl Lowe & John Best & John Best \\
2 & John Best & Phill Savidge & Phill Savidge \\
3 & Phill Savidge & lan Jackson & lan Jackson \\
4 & lan Jackson & Andy Lewis & Andy Lewis \\
5 & Andy Lewis & Paul Tunkin & Paul Tunkin \\
6 & Paul Tunkin & Todd Permenter & Todd Permenter \\
7 & Graham Coxon & Pearl Lowe & Simon Mason \\
8 & Saul Galpern & Miki Berenyi & Miki Berenyi \\
9 & Marijne van der Vlugt & Adrian Webb & Adrian Webb \\
10 & Todd Permenter & Justin Welch & Pearl Lowe \\
\hline
\end{tabular}


Figure 3: G2 sub-network, scaled by Betweenness

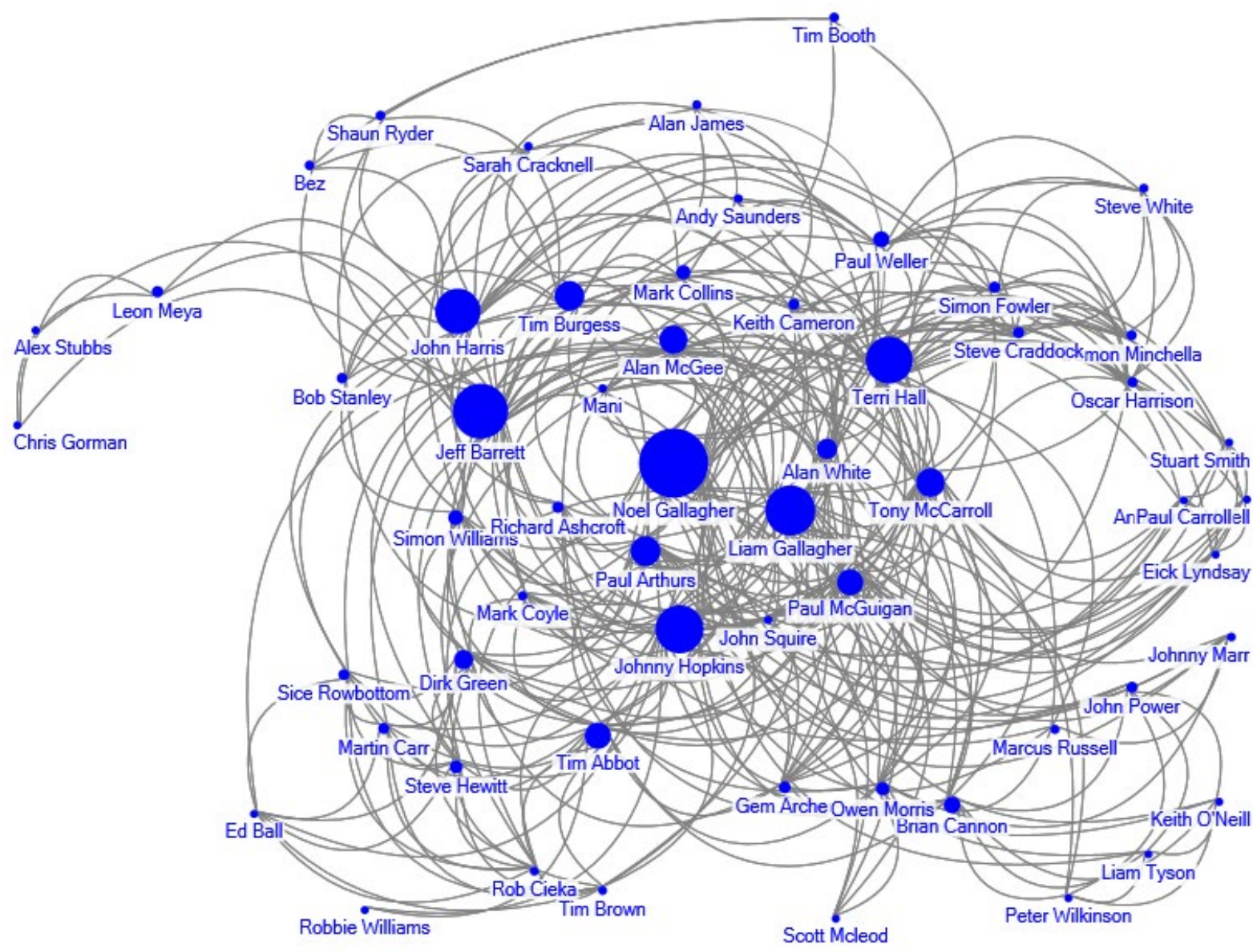


Table 3: Centrality Measure Ranking of Bounded G2 Network

\begin{tabular}{clll}
\hline Rank & Betweenness & Closeness & Degree \\
\hline 1 & Noel Gallagher & Noel Gallagher & Noel Gallagher \\
2 & Jeff Barrett & Liam Gallagher & Liam Gallagher \\
3 & Liam Gallagher & Johnny Hopkins & Johnny Hopkins \\
4 & Johnny Hopkins & Paul Arthurs & Terri Hall \\
5 & Terri Hall & Terri Hall & Paul Arthurs \\
6 & John Harris & Paul McGuigan & Paul McGuigan \\
7 & Paul Arthurs & Tony McCarroll & Tony McCarroll \\
8 & Tim Burgess & Jeff Barrett & Jeff Barrett \\
9 & Tony McCarroll & Alan McGee & Alan McGee \\
10 & Alan McGee & John Harris & John Harris \\
\hline
\end{tabular}

\footnotetext{
' See http://en.wikipedia.org/wiki/List_of_Britpop_musicians.

ii This is despite his name being mentioned by lots of other key actors in the network and with many having described him as their 'friend'. This hole in the data is recognised as a weakness in this research.
} 